\title{
Stronger together: Strategies to protect local sovereignty, ecosystems, and place-based communities from the global fossil fuel trade
}

\author{
Maggie Allen ${ }^{\mathrm{a}, *}$, Stoney Bird ${ }^{\mathrm{b}}$, Sara Breslow ${ }^{\mathrm{c}}$, Nives Dolšak ${ }^{\mathrm{a}}$ \\ a University of $W$ ashington, School of Marine and Environmental Affairs, 3707 Brooklyn Avenue Northeast, Seattle, WA 98105, United States \\ b Former corporate lawyer, part of leadership of Coal-Free Bellingham and Living Democracy during the events described in this article, 1346 Humboldt St, \\ Bellingham, WA 98225, United States \\ ${ }^{\mathrm{c}}$ University of Washington, Center for Creative Conservation, Box 355674, Seattle, WA 98195, United States
}

\section{A R T I C L E I N F O}

\section{Keywords:}

Neoliberalism

Environmental justice

Social movements

Fishing rights

Fossil fuels

Community activism

\begin{abstract}
A B S T R A C T
In the Pacific Northwest, residents are mobilizing to prevent the coastal export of fossil fuels and protect unique ecosystems and place-based communities. This paper examines the diverse groups, largely from the Bellingham area, and how they succeeded in blocking construction of what was to be the largest coal-shipping port in North America, the Gateway Pacific Terminal (GPT). Tribes, environmental organizations, faith-based groups, and other citizen groups used a multitude of approaches to prevent development, both independently and in concert. This paper reviews the various ways in which the groups collaborated and supported one another to resist the neoliberalization of the coast and support local sovereignty, unique ecosystems, and place-based communities. Groups like Power Past Coal, Protect Whatcom, and Coal-Free Bellingham fought for important and protective changes and evidenced communitywide political support, but the sovereign rights of the Lummi Nation were the legal bar to constructing the coal terminal.
\end{abstract}

\section{Introduction: the expansion of fossil fuel exports in the Pacific Northwest}

During the past four years, the Pacific Northwest (British Columbia, Canada, and Washington and Oregon, USA) faced 28 proposals that would support the export of fossil fuels to Asia [1]. However, the regulatory agencies with authority to permit construction of these terminals have denied all but three of the proposed projects: an oil port, Tesoro Savage Vancouver Energy Distribution Terminal in Vancouver, Washington, a coal port, Millennium Bulk Terminal, in Longview, Washington, and a liquefied natural gas (LNG) terminal on Lelu Island near Prince Rupert, British Columbia. This article examines approaches used by Washington coastal communities to successfully challenge what would have been the largest coal terminal in North America, the Gateway Pacific Terminal (GPT) in Bellingham, Washington [2].

For years, Washington residents have worried about the safety, health, and environmental problems that accompany fossil fuel terminals and refineries. The most recent accident was the June 3, 2016 derailment of a train carrying Bakken crude across Oregon to the port of Tacoma, WA. Sixteen cars derailed, four of which exploded and burned for a day before firefighters were allowed to approach. Communities were evacuated, and oil appeared in the Columbia
River the next day [3]. Tribes and environmental organizations believe that such export activities and facilities pose a risk to public and environmental health [4].

This paper examines the policy and legal actions of 12 diverse community groups to halt the construction of the GPT in Bellingham, Washington. It begins with background on the GPT project and an overview of the policy and legal processes required for permitting or denying a fossil fuel project in the United States. The paper then introduces the main participants involved in opposing the GPT, namely the Lummi Nation, which successfully cited treaty-fishing rights to block the project. It explains how these various groups worked together or independently, drawing upon diverse sets of beliefs and skills, in their attempts to stop the fossil fuel export project. Last, this paper discusses benefits and challenges of this movement that may inform similar social movements. It highlights the importance of tribal and non-tribal alliances and grassroots efforts to affect the policy and legal process.

\section{The Gateway Pacific Terminal}

In 1992, Pacific International Terminals (PIT), a venture/partnership between SSA Marine and Westshore Terminals, asked the Army Corps of Engineers for permission to build a pier that would ship bulk

\footnotetext{
* Corresponding author
} 
goods out of Cherry Point. Although the Whatcom County Council allowed for a shoreline and a development permit in 1997, the Washington Department of Ecology, Washington Fish and Wildlife, and a variety of citizen groups appealed the County's decision to Washington's Shoreline Hearings Board. In 1999, the parties reached a settlement, resulting in the halting of port development [5].

In 2010, SSA Marine, one of the largest marine operators in the world, once again announced plans to build the GPT at Cherry Point, this time with a much larger facility that would include the export of coal [6]. Although the 1855 Treaty of Point Elliot preserved the Lummis' ability to access their traditional fishing grounds at Cherry Point, they ostensibly lost formal ownership of the land at Cherry Point in 1872, when a Presidential Executive Order allowed the Bureau of Indian Affairs to illegally sell the property to non-indigenous squatters [7]. Now it is an industrial landscape, hosting two oil refineries and an aluminum smelter [8]. If completed, the GPT would have been the largest coal-export terminal in North America, shipping 54 million metric tons of commodities per year, including coal, on 487 vessels [9]. Coal producer Cloud Peak Energy had purchased a $49 \%$ stake in the GPT and planned to ship 17.6 million tons of coal, transported by rail from the Powder River Basin 1300 miles away [10].

The U.S. Army Corps of Engineers was the main regulatory agency responsible for the federal environmental review under the National Environmental Policy Act (NEPA). Whatcom County and Washington Department of Ecology led the state's environmental review under the State Environmental Policy Act (SEPA) [2]. The Army Corps' task was to make sure the project was following federal laws, commitments, mitigation measures, and permit decisions. This included assuring that the project adhered to tribal trust responsibilities, which included consulting tribes over issues such as fishing rights, fisheries habitat, and cultural resources [11].

\subsection{Contested economic benefits}

An economic analyst hired by GPT claimed that the GPT would introduce 863 total jobs to the Whatcom County economy during the first phase of the terminal's development and 1229 direct jobs once the GPT was completed. The terminal was also projected to contribute $\$ 8.1$ million in state and local tax revenue annually and $\$ 126.3$ million to annual personal wages in Whatcom County [12]. In general, proponents of the GPT believed that this project would help keep youth in the county instead of going elsewhere to look for jobs [13]. The indigenous Crow Nation in Montana also supported the GPT because 9 million tons of coal lies beneath their land and its extraction for export would aid their local economy [4]. They owned part of the GPT project, with the potential of earning $\$ 10$ million over the first five years of the project [13].

CommunityWise Bellingham, a group organized to evaluate the GPT project, contested these claims. Their analysis - described below concluded that disruptions from the project could negatively affect employment and economic growth in ways that outweigh the claimed benefits [14].

\subsection{Expected environmental and social impacts}

In addition, various local groups claimed the project would impact Cherry Point's habitats for birds, marine invertebrates, marine mammals, and many species of fish, including a genetically distinct species of herring. To protect these and other species in the local ecosystem, Cherry Point was declared an aquatic reserve under the Washington State Department of Natural Resources [8]. Although this designation does not affect private land ownership, opponents to the GPT often cite herring and other ecosystem components in the environmental assessments $[15,16]$. During the environmental review and the Army Corp's decision-making process, the Lummi Nation and local environmental groups stated their concerns that the GPT would increase underwater vessel noise, shipping accidents, oil spills, and threats to wildlife. They also believed the GPT would block access to fishing and harvest of wildlife. For example, the Lummi Nation claimed the GPT would impact their ability to access their treaty-protected tribal fishing grounds [17]. A Vessel Traffic and Risk Assessment Study, required as part of the commencement permit process for the GPT, estimated "that GPT would increase the Lummi fishing disruption" by 15 crab pots per Lummi fisherman per year [18].

\subsection{The policy, legal and economic context}

Under U.S. federal and state environmental laws, a major coastal infrastructure project such as the GPT requires formal review of its potential environmental impacts, with opportunities for public review and comment. In a democratic process such as this, policy changes are ideally approved if they foster public interest. However, even in the most ideal case, most policies have winners, who stand to benefit from a policy change, and losers, who stand to bear the costs of a policy enactment. Proponents of the fossil fuel terminals claimed that they would increase benefits to local communities because they would increase local employment [19]. On the other hand, a large crosssection of local communities argued it would threaten treaty rights, unique ecosystems, and place-based values [9].

To balance the impact of a policy on winners and losers, costbenefit analyses, the cornerstone of policy-decision making in the U.S.A., employ Kaldor-Hicks compensation criterion. This criterion recommends that if policy winners gain sufficiently to theoretically compensate losers, the policy should be adopted. However, adoption of this criterion in public policy has two important challenges. First, opponents of the policy may disagree with the values and analytical assumptions underpinning cost-benefit analyses. For example, CommunityWise Bellingham opposed expansion of the GPT by challenging the analytical assumptions of its proponents [20]. Second, policy losers may worry that a policy change will cause irreversible damages to the ecosystems and/or that they will not actually be compensated for decline in their wellbeing (whether social, economic, or cultural). These concerns motivate policy losers to mobilize and engage in the policy process.

When organizations and individuals become mobilized over an issue, they can pursue multiple avenues to affect the policy decision. Due to built-in divisions of power, the U.S. policy process enables advocates to influence policy through the legislative, executive, and judicial branches of federal, state and local governments [21]. Historically, Washington State has been among the greenest states in the USA, making the state regulatory and executive agencies more likely to consider environmental concerns in their economic and social development decisions [22]. Further, Washington has carbon dioxide emission targets, making its state agencies potentially more concerned about fossil fuel development [23]. Recently global climate change advocates developed Initiative 732, utilizing the ballot measure process to press the Washington legislature to adopt a carbon dioxide tax [24]. In sum, the public, the executive branch, and the legislative branch in Washington State are among the most active people in environmental issues in the nation.

Policy actors will select from these multiple policy avenues depending on which route they believe will be the most effective [25]. They may not always agree on which is the best route. In the case of GPT, some believed the regulatory and permitting route was the appropriate pathway and used their resources to mobilize the public to engage in this process, including the Lummi Nation and their coalition as well as the Protect Whatcom group [26]. The Lummi Nation chose to influence the GPT permitting process by relying on their federal treaty rights and permitting process. They claimed that the Cherry Point GPT would violate the Treaty of Point Elliot of 1855 and the Boldt Decision of 1974, which re-asserted their right to fish in their usual and accustomed (U \& A) fishing grounds around Cherry Point, Washington [27]. 
Policy advocates may alternatively choose non-legal routes to effect change. Several actors in the Bellingham case believed the regulatory process was biased. They observed that the public process allowed the public to comment - but that the public's comments were not binding on the ultimate decision-makers. Proponents, on the other hand, could claim denial of civil rights, if they had met the regulatory requirements and were nonetheless denied a permit. These members of the Bellingham community decided to engage in civil disobedience. For example, Coal-Free Bellingham attempted to achieve a citywide ordinance that would ban the coal trains [26]. It did so through the initiative procedure, which in itself is legal, but if adopted, the content of the ordinance would have violated federal and state law in ways that are discussed later. It was the content of the proposed ordinance that would have constituted civil disobedience. The group proceeded in this fashion because they had no confidence that prevailing regulatory principles would protect the environment and the community. Furthermore, under prevailing law, local communities have no inherent powers, but only the powers granted by the state. The initiative was aimed both at underlining the importance of environmental issues for the community and the world, at asserting the right of local communities to govern themselves, and at limiting corporate power. The group believed that neither the state nor the federal government was actually going to protect the community or the world from the coal project. In this they were supported by a growing body of scholarship, which shows that the environmental laws have not achieved their ostensible aims in the face of the continuing pressure from capitalist "economic" development [28]. In the end the initiative was kept from the voters because it went beyond what municipalities are currently allowed to do.

Last, there is a question of working together or alone in the policy process. Mobilized actors can opt to engage in the policy process unilaterally, entirely controlling the ways the issue is framed (e.g., as an environmental, health, sovereignty, and/or treaty rights concern) and the suite of policy avenues to pursue. On the other hand, actors may choose to pool resources to increase their policy impact. While this division of effort may be viewed as a loss of control by any particular group, it can increase the visibility of the issue and generate support across policy venues, as discussed below.

\subsection{A neoliberal economic and political climate}

Since the founding of the United States, a significant line of thinking has been that government exists to support business. During the Reagan presidency, neoliberalism, a variation of this theme was introduced. The idea is that human well-being can best be achieved through individual freedom and enterprise backed by individual property rights, free markets, and free trade. The GPT proposal fit perfectly into this mode.

Manifestations of neoliberalism are the international trade agreements like WTO, NAFTA, and the proposed Trans-Pacific Partnership (TPP), tax breaks for the wealthy, a relaxed attitude towards mergers among competing companies, removal of restraints on financial institutions permitting joint ownership of commercial banks, investment banks and insurance companies, and failure to regulate new instruments of speculation like derivatives. In this way of thinking, the interests of business and pro-globalization elites rightfully override the "parochial" interests of local communities. The international media may use their powerful role in shaping public opinion to defend globalization, for example, by construing assertions of local control as racist and misinformed [29].

From its beginning, the legal system of the United States has favored the privileges of businesses and their wealthy owners over local communities. The commerce clause of the Constitution prohibits local communities and states from interfering with "interstate commerce," which is primarily composed of the activities of large companies. Since the end of the 19th century, local governments have been explicitly limited to the powers granted to them by the State [30]. They have no inherent powers of self-government, although Washington State has assigned them certain powers like public safety, certain kinds of taxation, and the management of growth under the Growth Management Act. Local rules can be preempted by state or federal law even when necessary to protect local well-being, a principle that occasionally benefits tribal governments when they oppose local governments.

In addition, the Environmental Impact Statement (EIS) has no force in compelling the ultimate decision on whether to grant a permit for a project. Proponents must prepare one and there is a public process in devising the scope of the EIS and its final crafting, but the decision-makers are not ruled by it. The remainder of this article examines methods used by the most active opponents of the GPT to protect their ecosystem, well-being, and quality-of life [31].

\section{Methods}

In order to better understand the actions and values of the groups involved in halting the GPT, this paper employs a case study approach [32], allowing for in-depth study of the contemporary process of developing opposition to fossil fuel expansion in Bellingham, Washington. Research took place between 2014 and 2016. The authors collected primary data from participant observation and interviews and secondary data from organizations' websites and reports, event briefs, and newspaper articles.

One of the authors participated in the founding and leadership of Living Democracy and Coal-Free Bellingham beginning in early 2010 and ending with the groups' effective demise in late 2012. Reports from these groups and others (Whatcom Docs, CommunityWise Bellingham, and Bellingham Twelve) are from personal experience of weekly strategy group meetings over three years, conversations with people who were involved in those groups, and from news reports and websites.

From 2015-2016, the first author attended seven Lummi-organized events and meetings, and conducted twelve personal interviews with members of the Lummi Nation, environmental groups, and faithbased organizations. To help determine: (1) how these groups formed, (2) how they are affecting policy, and (3) the groups' various beliefs, this research employs the Advocacy Coalition Framework (ACF). Further analysis of this qualitative data provides guidance on how advocates gathered their resources and united their core beliefs to successfully form future coalitions. According to the ACF, coalitions are formed when members share the same policy beliefs with an aim of achieving a particular goal. Even if these people have different interests, they are united and conflicts are mediated by their similar overall belief. These coalitions help gain the attention of policymakers because the members often come up with effective strategies to engage other stakeholders [33].

According to the ACF, people are motivated by their "deep core" beliefs and their "policy core" beliefs. Deep core beliefs, such as religious beliefs, represent a person's or an organization's central beliefs that are unaffected by change. An individual's or an organization's primary policy core beliefs, such as a belief that it is important to protect nature from neoliberal forces, are specific and are also hard to change, but they are the beliefs that more frequently unite allies and form coalitions. Policy core beliefs can be someone's perceptions of the severity of a problem, causes of an issue, effectiveness of a policy tool, or the appropriate relationship between the economy and the government [34].

For the portions of the paper based on qualitative, retrospective research, questions were structured around the ACF and other general policy process themes. The key research questions were: (1) Who stands to lose with the expansion of fossil fuel trade in this community? (2) Who among the losers mobilized to oppose the expansion of fossil fuel trade in this community? (3) How did these actors use the tools available in the U.S. policy process to block the expansion? (4) How did 
Table 1

Local and other groups opposing the GPT project.

\begin{tabular}{|c|c|c|c|}
\hline Group & Reach & Type of group & Actions \\
\hline Lummi Nation & Local & Tribal & $\begin{array}{l}\text { Assertion of sovereign } \\
\text { treaty rights, cultural } \\
\text { rights, awareness- } \\
\text { raising events (totem } \\
\text { pole journeys, public } \\
\text { forums, media) }\end{array}$ \\
\hline Re-Sources & Local & \multirow[t]{3}{*}{ Environmental } & Organization of \\
\hline Sierra Club & National & & rallies, petitions, \\
\hline Climate Solutions & Statewide & & $\begin{array}{l}\text { letter-writing, EIS } \\
\text { comments }\end{array}$ \\
\hline Earth Ministry & Statewide & \multirow[t]{3}{*}{ Faith-based } & \multirow{3}{*}{$\begin{array}{l}\text { Encouragement, } \\
\text { moral claim }\end{array}$} \\
\hline $\begin{array}{l}\text { Bellingham } \\
\text { Unitarian } \\
\text { Fellowship }\end{array}$ & Local & & \\
\hline $\begin{array}{l}\text { Bellingham } \\
\text { Friends } \\
\text { Meeting }\end{array}$ & Local & & \\
\hline $\begin{array}{l}\text { Whatcom } \\
\text { Democrats }\end{array}$ & $\begin{array}{l}\text { Local, with } \\
\text { nationwide } \\
\text { fund-raising }\end{array}$ & Political Party & $\begin{array}{l}\text { Polling, electoral } \\
\text { campaigns for County } \\
\text { Council }\end{array}$ \\
\hline $\begin{array}{c}\text { CommunityWise } \\
\text { Bellingham }\end{array}$ & Local & Think Tank & $\begin{array}{l}\text { Commissioning of } \\
\text { economic studies, fact } \\
\text { checking }\end{array}$ \\
\hline Whatcom Docs & Local & Doctors & $\begin{array}{l}\text { Describing health } \\
\text { threats surrounding } \\
\text { the GPT project }\end{array}$ \\
\hline Protect Whatcom & Local & Political activist & $\begin{array}{l}\text { Yard signs, } \\
\text { commentary }\end{array}$ \\
\hline Coal-Free & Local & Community & Municipal civil \\
\hline Bellingham & & Rights & disobedience \\
\hline (with Living & & Campaign & \\
\hline Democracy) & & Organization & \\
\hline Bellingham Twelve & Local & Active Citizens & $\begin{array}{l}\text { Individual civil } \\
\text { disobedience }\end{array}$ \\
\hline
\end{tabular}

these actors build a coalition to increase their resources and the ability to oppose fossil fuel trade expansion in their community? Once the interviews were completed and transcribed, they and the event observations were manually coded to collect keywords and themes. This phase allowed themes inherently emergent in the data to be identified [35].

\section{Approaches to blocking the GPT}

In this legal, political, intellectual, and economic climate, members of the Bellingham community were motivated by a large variety of concerns and used a wide range of approaches to confront the GPT project (Table 1). Some of these actors used the federal and local regulatory and permitting process to influence the outcome (the Lummi Nation, Coal-Free Bellingham). Others used the political process by mounting a people's initiative (Coal-Free Bellingham) or getting anti-coal politicians elected to local government (Whatcom Democrats). Some groups focused on providing information about the negative impacts of GPT on the local public health, ecosystems, and space-based culture (the Lummi Coalition, Whatcom Docs, and CommunityWise Bellingham). Another group engaged in civil disobedience (the Bellingham Twelve). The following narratives describe these actors, their chosen strategies, and their rationales (Table 1).

\subsection{Building an indigenous-led coalition}

The Lummi Nation, with the biggest native fishing fleet on the U.S. West Coast [13], has been fighting for their right to fish since European contact. In 1855, they signed the Treaty of Point Elliot with the U.S. government [36]. This treaty stated that the "right of taking fish at usual and accustomed grounds and stations is further secured to said Indians in common with all citizens of the Territory" [37]. The Boldt
Decision of 1974 solidified tribal rights to fish in Washington. The State Supreme Court awarded the Lummi Nation, as well as all twenty other Washington indigenous nations, $50 \%$ of the state's catchable fish [38]. This court decision affirmed the tribal sovereignty of the Lummi Nation and assured access to their traditional and accustomed fishing grounds around Cherry Point.

Because most of their commercial fishing occurs at Cherry Point [39], the Lummi Nation cited the Boldt Decision and the Treaty of Point Elliot in claiming that the development would violate their fishing rights. The Lummi Nation's direct authority and treaty with the federal government allowed them to assert their sovereignty and establish a leadership position amongst non-tribal communities [27]. The Lummi Nation primarily asserted this influence when working with the various organizations of the umbrella group Power Past Coal, which encouraged its members to "stand with the Lummi against Big Coal" [40].

The environmental organizations that worked with the Lummi used a variety of policy tools such as: hosting forums and workshops for writing comments for the EIS scoping process, writing letters to Congress and the Army Corps, coordinating events, and generally providing a "grassroots push." For example, Climate Solutions connected the community to the problem by emphasizing local impacts such as noise pollution, health detriments, and train traffic. The Sierra Club also helped with advertising through banners and stickers around the Totem Pole Journey. They hosted movie showings, displayed murals, and hosted a silent auction. Because the Sierra Club is a national organization with an office in Washington D.C., members called into the offices of the Army Corps and sent around 25,000 letters to Congress, pressing its members to recognize that the coal exports threaten the Lummi's fishing rights.

Faith-based organizations used their political influence, their communication skills, and their organizing ability to effect change. For example, the Bellingham Unitarian Fellowship, mainly under the leadership of Beth Brownfield and Deb Cruz, leaders of BUF's Native American Connections Committee, encouraged its members to write letters to the Army Corps and pressured elected officials to support treaty rights. They provided space for the Lummi Nation to outreach to other social justice networks through venues such as film festivals, workshops, and other church events. The religious organizations also contacted other faith communities around the nation to host similar events where similar projects are threatening indigenous land.

\subsection{Independent organizations involved}

\subsubsection{Whatcom democrats elect the county council}

The Whatcom County Council was one of the three key decisionmaking bodies for the project. The two others were the U. S. Army Corps of Engineers and the Washington State Department of Ecology, who suspended its State Environmental Policy Act's (SEPA) EIS process on April 1, 2016, upon PIT's request while waiting for the Army Corp's response [41]. Among these three, the County Council had unique features. First, the people of the community elected the council members. This feature might have been thought to favor the strong anti-coal sentiment. Yet, the County Council was limited by a requirement to act in a "quasi-judicial" capacity. In other words, its legal mandate was to "apply the law" rather than carry out any political mandate from the electorate. If the permit application fulfilled all the requirements of the law, the Council was legally bound to grant it, or else subject the County to potential liability for the proponent's lost profits. Because of the "quasi-judicial" character of their office, campaigning candidates were advised not to state their views on the project for fear of risking later claims of "bias."

Despite these obstacles, the Whatcom Democrats proposed slates of candidates in 2013 and 2015 who were all known to oppose the project, and who were all elected, so that by 2016 the entire Council was composed entirely of nominal opponents to the GPT. In 2016 the Council stalled in considering amendments to the County's 
Comprehensive Plan that would bar fossil fuel projects at Cherry Point, and their final decision remains uncertain as of this writing. Despite these ambiguities in what the Council felt that it could do, it was clear that once again the community as a whole had expressed its wishes with crystal clarity: it wanted no part of supporting further fossil fuel projects.

\subsubsection{CommunityWise Bellingham}

Formed in mid-2012 in response to the proposed coal project, CommunityWise Bellingham defined its role as a fact-checker of GPT's economic claims, and commissioned a number of economic reports on the project's likely effects. The first, released in 2012, studied the project's effects on local quality of life and jobs. These included detracting from Bellingham's status as a vacation and retirement destination because of train noise and emissions, and disrupting plans to redevelop the waterfront, which is separated from the rest of the city by the rail line. The report concluded that if these negative effects of the project reduced overall job growth by one-sixth, the result would be a net negative effect on jobs in the county. The disruption was projected to be particularly severe for the Bellingham waterfront, where local and state agencies have committed $\$ 40$ million for redevelopment of the former Georgia Pacific pulp mill site. Some of the disruption for the site could be mitigated, but at great expense that could fall on local residents, outweighing the claimed local government tax revenue increases. A second commissioned report, issued in 2015, looked at potential economic costs and risks of the project, noting that China, a major supposed market for the coal, was turning away from coalburning power plants because of air quality harm. This second report observed that property values of houses close to the rail line depreciated, while other single-family residences in the city stayed the same or increased [42]. It also revealed that the earlier Martin Associates report, "the Projected Economic Impacts for the Development of a Bulk Terminal at Cherry Point" (on which the GPT's economic claims were based), had used a jobs multiplier over 50\% larger than the multiplier recommended by the U.S. Bureau of Economic Analysis [43].

\subsubsection{Whatcom Docs}

When the coal project appeared on the scene, a group of 200 Whatcom County doctors coalesced to assess the literature on the human health effects of additional coal trains and coal port operations. They concluded that there was a problem, and that a more formal Health Impact Assessment should be built into the decision-making process [44]. A Health Impact Assessment would have been a departure from the usual permitting routine and therefore an amendment to existing law would be needed to include it. The group went so far as to propose this amendment, but did not propose not proceeding without the amendment.

\subsubsection{Protect whatcom}

Protect Whatcom came into being in 2012 as a Facebook page and a website. Its yard signs proclaiming "Coal Costs Us" were widespread. Its principal, Terry Wechsler, was a frequent contributor to Whatcom Watch, a local citizen-written monthly newspaper. The lively articles provided commentary on how to participate in scoping the Environmental Impact Statement, and other aspects of the regulatory process.

\subsubsection{Coal-Free Bellingham}

Many in the community had come to view environmental laws not as serving to protect the environment, but rather serving to legalize harm. In their view, it was not polluting companies that were being regulated, but the members of the public who might dare to oppose a corporate project [45]. Opportunities to participate in the process were onerous and tightly circumscribed, and the legal system did not allow the public to have a decisive role and determine the final result. What is more, companies could deduct the expenses of preparing their permit applications and fighting any resulting legal contests - in effect receiving a tax subsidy for legalizing their pollution operations. For the municipalities and small community groups on the other side, there was no such tax subsidy.

Around the United States, communities had begun stepping outside the constraints of the legal system when they were faced with a corporate project that had received all its federal and state permits and that would cause irremediable local harm. They were often advised and defended by a fee-free non-profit environmental law firm called Community Environmental Legal Defense Fund [46].

In Bellingham, groups had begun forming in 2010 to study these concepts. When the GPT coal project appeared on the scene in 2011, these groups saw an opportunity to put their ideas into practice. To give their effort organizational structure they formed a non-profit educational arm called Living Democracy, which sponsored public seminars on these concepts of resistance and reform. They also formed a campaign arm called Coal-Free Bellingham.

The aim was to pass a city ordinance - a Community Bill of Rights that would block the coal trains, deny corporate personhood to offending railroad companies, and reassert the community's right to govern itself. The site of the GPT project was outside the city limits, yet the tracks leading to the proposed coal port ran along the city's waterfront, so a city ordinance could prohibit the transportation of coal through the city. The Bellingham City Council refused to initiate this ordinance, so the group mounted a citywide initiative campaign. Their intention was to gather just under 5000 signatures from voters in the city, to spur a citywide vote on the initiative in the 2012 general election. They gathered 10,000 signatures, only to learn that the City planned to sue Coal-free Bellingham to keep the initiative off the ballot. Burlington Northern, the railroad in question, joined the City in its threatened suit. Under the law as it stands, a local community that stands in the way of "commerce" must reimburse the company concerned about lost profits [47]. Thus, in the same way as other social justice movements in the past, the campaign for the Bellingham Community Bill of Rights, and the other campaigns like it around the country, became in essence political campaigns, which expose the inequity of the legal system as it stands.

\subsubsection{The Bellingham Twelve}

Just as the members of Living Democracy and Coal-Free Bellingham had decided that the legal system was inadequate to protect the community and environment, others reached the same conclusion. Instead of municipal civil disobedience, they chose the route of individual civil disobedience. In December of 2011, twelve individuals blocked the train tracks, several of them chaining themselves to the tracks. When they were prosecuted for trespass, they pleaded the doctrine of necessity, under which a person can commit what is otherwise a crime because doing so protects a vital interest and the legal system offers no adequate resource. In this case, the vital interest was the stability of the world's climate system, which was being threatened by the burning of coal. Although other courts around the country are recognizing the defense in similar cases, the Bellingham Municipal Court did not.

\section{Building coalitions}

\subsection{Lummi-Led coalition}

As explained above, in 2010, the Lummi Nation partnered with local environmental groups, faith-based organizations, and other tribal nations from both Canada and the U.S to oppose the GPT (Fig. 1). These groups include: Climate Solutions, RE-Sources for Sustainable Communities, Earth Ministry, the Bellingham Unitarian Fellowship, and the Sierra Club. This unique partnership has been successful in uniting traditionally independent indigenous, faith-based, and environmental groups over opposition to coal exports and construction of 


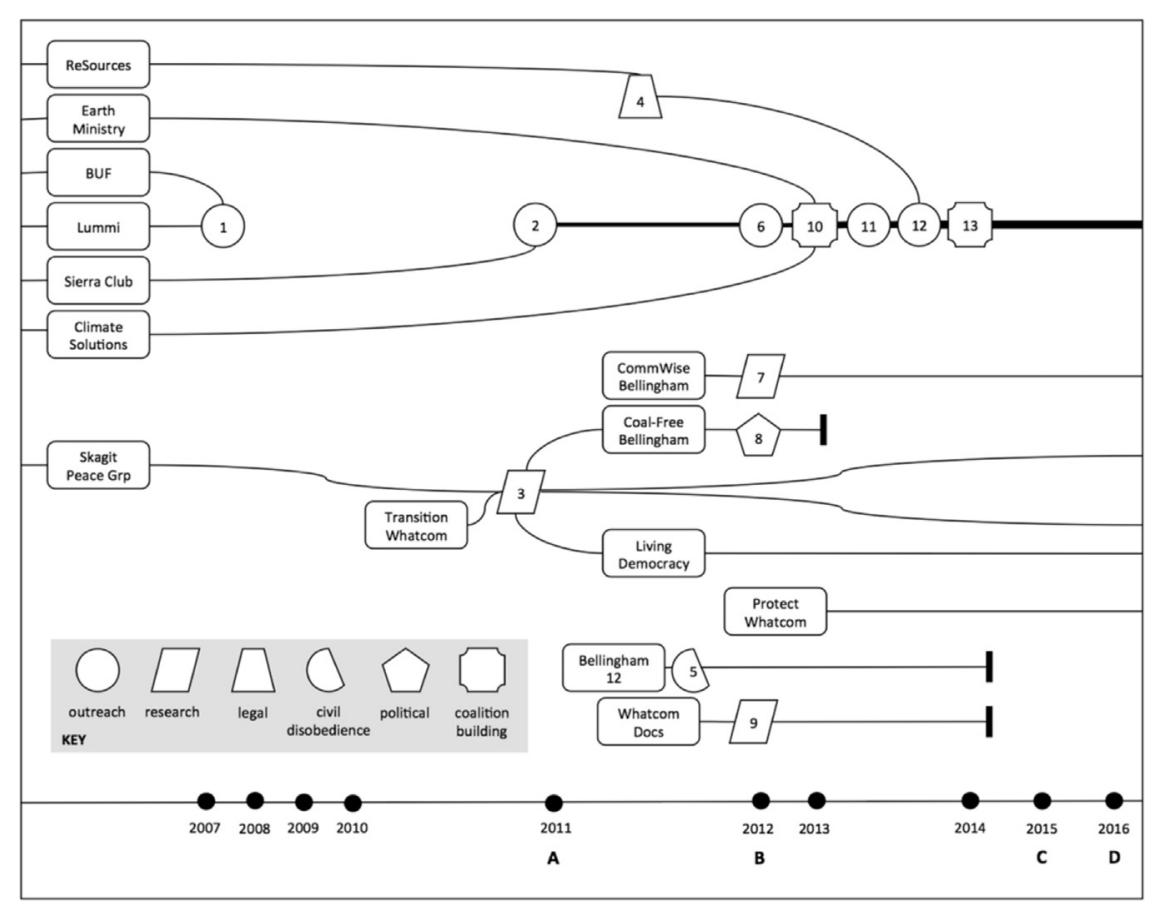

Fig. 1. Timeline of Anti-GPT organizations' actions (See Table 2 for details).

the GPT. Together, using their different sources of power and resources, they formed a coalition to take on the coal industry and block development for the GPT.

The main environmental groups' relationship with the Lummi Nation generally began in 2010, when many of them met to discuss how to stop the coal terminal. For example, the Lummi Nation informed the Sierra Club that they needed a better way to communicate their concerns, so the nonprofit helped develop materials to narrate how the GPT would affect the Lummi way of life. When Whatcom County inspected the land around Cherry Point in 2011, they found illegal land clearing and major damage to wetlands. In response, RE Sources sued PIT for filling wetlands without a permit [2]. Members of the Lummi Nation, mainly those involved in the fishing industry, asked for documents resulting from the lawsuit, and became interested in creating a partnership. To help resolve the conflict, SSA Marine, the subsidiary of PIT who proposed to build the GPT, gave the Lummi a $\$ 400,000$ check that provided the Lummi Nation with resources needed to conduct a technical review of the proposal, which is a routine matter for such projects. In 2012 the Lummi Nation made public their opposition to the project, burning a "fake check given to them by SSA Marine" in 2012 to make it clear that no amount of money would convince them to allow the building of the coal terminal [48]. In 2013, a settlement with Re-Sources was reached, and PIT was required to pay $\$ 1.6$ million. This lawsuit was one in a series of events that promoted the relationship between the Lummi Nation and RE-Sources, particularly with the Sovereignty and Treaty Protection Office.

Faith-based groups were similarly supportive. In 2007, Beth Brownfield of the Bellingham Unitarian Fellowship (BUF) assisted the Lummi Nation with their Global Canoe Journey with "whatever they needed," including acknowledging them as the original inhabitants of the local lands and waters. In 2012, the Unitarian Universalist Association officially stated that they were standing with the Lummi Nation against the GPT. Brownfield invited 90 religious leaders and 50 different organizations to speak on the issue in 2013, which helped connect the Lummi Nation with the Sierra Club, the League of Women Voters, college youth groups, and others. In addition, Deb Cruz, cochair of the BUF's Green Sanctuary program, which focuses on environmental justice and religious education, helped bridge the environmental and faith-based communities and assisted with social action. After this event, The Bellingham Unitarian Fellowship (BUF) and the Lummi Nation worked together on most Bellingham-based events related to the coal terminal.

Earth Ministry, a non-profit that engages the faith community in environmental stewardship and advocacy, has also been involved for a number of years, training faith leaders, holding breakfasts, and hosting churches for stops along the Totem Pole Journey. They also hosted an event at Seattle University, where key activists of the Lummi community spoke about the negative aspects of the GPT on their livelihoods, and raising a couple thousand dollars. These various events provided a unique opportunity for three groups to work and stand together.

\subsection{Informal working relations with and among the other groups}

In contrast to the Lummi-led coalition, there was no evidence of formal connections with or among the other groups opposing the GPT (Whatcom Democrats, CommunityWise Bellingham, Whatcom Docs, Coal-Free Bellingham, and the Bellingham 12). In fact, Coal-Free Bellingham and CommunityWise Bellingham, explicitly agreed to follow their respective courses independently, each recognizing the value of what the other was doing. There were, however, numerous informal personal connections among the groups. For example, a member of the Steering Committee of Living Democracy worked with Beth Brownfield in facilitating the Lummi's efforts to communicate with religious groups and the community at large. Another member of Living Democracy worked actively on the Whatcom Democrats' voter contact campaign (see Fig. 1 for more information).

\section{Policy goals and beliefs of the lummi-led coalition}

For this campaign, interviews suggested the issue of climate change had brought all groups together, and many of the members of the environmental organizations were concerned with upholding treaty rights and protecting indigenous communities against industrialization and capitalism. Both the environmental and faith-based groups had the same policy goal as the Lummi Nation: to prevent the construction of a coal terminal at Cherry Point, Washington.

To better understand the factors uniting these diverse groups, the Advocacy Coalition Framework (ACF) was applied to identify and 
Table 2

Timeline of organizations.

\begin{tabular}{|c|c|c|}
\hline Year & Action & $\begin{array}{l}\text { Key to } \\
\text { Fig. } 1\end{array}$ \\
\hline 2007 & BUF helps Lummi with Global Canoe Journey & 1 \\
\hline \multirow{2}{*}{2010} & Lummi asks Sierra Club to help narrate impacts & 2 \\
\hline & $\begin{array}{l}\text { Skagit Peace Group \& Transition Whatcom begin studying } \\
\text { nationwide CELDF-led community rights movement }\end{array}$ & 3 \\
\hline \multirow[t]{3}{*}{2011} & PIT submits proposal to build GPT & A \\
\hline & RE Sources sues PIT for filling wetlands without permit & 4 \\
\hline & $\begin{array}{l}\text { Approximately } 50 \text { community members block a coal train. } \\
\text { Bellingham 12, who chain themselves to the tracks, charged } \\
\text { with trespass }\end{array}$ & 5 \\
\hline \multirow[t]{5}{*}{2012} & $\begin{array}{l}\text { SSA Marine offers Lummi the required } \$ 400,000 \text { to } \\
\text { compensate for their technical review of the proposal } \\
\text { PIT conducts illegal clearing on Cherry Point and damages a } \\
\text { registered archaeological site. }\end{array}$ & \\
\hline & $\begin{array}{l}\text { Lummi burn a fake check given in } 2012 \text { to imply that no } \\
\text { amount of money would convince them to allow the building } \\
\text { of the coal terminal }\end{array}$ & 6 \\
\hline & First CommunityWise Bellingham reports issued & 7 \\
\hline & $\begin{array}{l}\text { Coal-Free Bellingham campaign for a Community Bill of } \\
\text { Rights - 10,000 signatures gathered }\end{array}$ & 8 \\
\hline & Whatcom Docs issue their report & 9 \\
\hline \multirow[t]{4}{*}{2013} & Scoping period closes. 125,000 comments submitted. & B \\
\hline & $\begin{array}{l}\text { BUF hosts Lummi Nation, whose members speak to } \\
\text { representatives of over } 86 \text { religious leaders from over } 36 \\
\text { religious organizations and over } 200 \text { activists representing } \\
\text { over } 44 \text { activist organizations. } \\
\text { Coal-Free Bellingham winds up }\end{array}$ & 10 \\
\hline & 1st Annual Totem Pole Journey & 11 \\
\hline & $\begin{array}{l}\text { Settlement reached between RE Sources and PIT, prompting } \\
\text { Lummi to ask for documents from lawsuit }\end{array}$ & 12 \\
\hline 2014 & $\begin{array}{l}\text { Lummi hosts Sacred Summit with environmental nonprofits, } \\
\text { other tribes, and concerned citizens. Second totem pole } \\
\text { journey. }\end{array}$ & 13 \\
\hline 2015 & $\begin{array}{l}\text { Lummi writes multiple letters to Army Corps requesting } \\
\text { denial of permit. Third totem pole journey. }\end{array}$ & $\mathrm{C}$ \\
\hline 2016 & Army Corps denies permit. Fourth totem pole journey. & $\mathrm{D}$ \\
\hline
\end{tabular}

analyze the organizations' policy core and deep core beliefs (results summarized in Table 2). This analysis suggested that the environmental, faith-based groups, and the Lummi Nation united around their strong desire to stop the coal terminal because of their policy core beliefs on environmental justice and climate change action, and their common beliefs allowed them to build strong, long-lasting relationships.

Results showed that the Lummi Nation was heavily committed to upholding their treaty rights, but they were also concerned about climate change impacts on their community and the impact on their traditional cultural properties at Cherry Point (Xwe'chi'eXen in the Lummi language). A Lummi Nation fisherman, for example, who identified as an "environmentalist by nature", discussed how he was already seeing impacts of climate change on his crab fishery and believed that the terminal would make the loss of fishing grounds worse. Climate change is related to the Lummi Nation's deep core belief, which centers on the sacredness of the land and their commitment to honor the treaties of the past. Another Lummi fisherman referenced the treaty in an interview: "If we don't do something, we're disrespecting those people who signed the treaty in 1855 who guaranteed our right to fish."

The faith-based groups believe spirituality is essential for human well-being and perceived the GPT as a human rights issue. Some directly referenced the issue of environmental justice; others said that there was a moral and ethical obligation to reject the terminal. Members of the Bellingham Unitarian Fellowship and Earth Ministry specifically mentioned environmental downsides of the terminal, including that it would be an environmental injustice (Table 3).
Table 3

Deep core and policy core beliefs of three groups resisting the GPT.

\begin{tabular}{llll}
\hline Beliefs & Lummi nation & $\begin{array}{l}\text { Faith-based } \\
\text { groups }\end{array}$ & $\begin{array}{l}\text { Environmental } \\
\text { groups }\end{array}$ \\
\hline Deep Core & $\begin{array}{l}\text { Sacredness of land } \\
\text { and fishing, } \\
\text { commitment to } \\
\text { honor the treaties }\end{array}$ & $\begin{array}{l}\text { Importance of } \\
\text { spirituality for } \\
\text { human well- being }\end{array}$ & $\begin{array}{l}\text { Environmentalism, } \\
\text { ecosystem preservation }\end{array}$ \\
Policy Core & $\begin{array}{l}\text { Climate change } \\
\text { and community } \\
\text { well-being }\end{array}$ & $\begin{array}{l}\text { Environmental } \\
\text { justice and human } \\
\text { rights }\end{array}$ & Environmental justice \\
\hline
\end{tabular}

\section{Benefits and future challenges}

On May 9, 2016, the U.S. Army Corps of Engineers denied the construction commencement permit of the Gateway Pacific Terminal project [49]. The formal decision was based solely on the Lummi Nation's legal treaty right, and claim, to access their fishing grounds. Although SSA Marine may follow up with a lawsuit or counter proposal because of their desire to build the coal terminal, the future for the GPT and other coal export terminal are uncertain. International coal prices have fallen drastically in 2015/2016 [50], and the demand for US coal in China is also decreasing, since U.S. coal producers cannot compete with Indonesian producers. In addition, policy and regulation are becoming more supportive of non-coal alternatives, including hydraulic-fracking, wind farming, and solar energy, which further threatens the future of coal in the U.S. [51].

Despite the fact that a weakening Asian market for coal did play a role, it is undeniable that the Lummi deserve the most credit for blocking the GPT. Without the Lummi, the Corps would have not likely denied the permit. The National Environmental Policy Act (NEPA) process would have gone ahead, and there was a high probability that SSA Marine would have built a coal port. The Lummi, for example, even influenced Goldman Sachs, which originally had a 49\% share in Carrix, Inc. (Parent company of SSA Marine). In 2014, Goldman Sachs sold their share, claiming that mostly market forces convinced them to back out [52]. However, just months before, a representative from the Lummi Nation and from the Swinomish Tribe were able to talk to the CEO of Goldman Sachs at the company's annual shareholder's meeting, with proxies received from the National Council of Churches. The Lummi member reminded the CEO that the terminal would be built on top of an ancient Lummi cemetery. A staff member of the Lummi Nation claims that the CEO did not want to "risk a bad investment on top of that, and they let us know in no uncertain terms that those three minutes were crucial."

At the same time, without the non-profits, the Lummi would have stood alone facing the Corps, and the Corps would not have had their political back covered in making the decision because overall, this was a legal decision in the context of a political battle. On May 14, 2016, Jewell James spoke at the Indigenous Day of Action in Anacortes, WA, part of the Break Free PNW event that called for a transition to $100 \%$ renewable energy. He recognized the coalition's importance in stopping the coal terminal: "We're glad that the citizen groups, the nongovernmental organizations, environmental groups...and the churches have all come together...United we can continue to work and win" [53]. On September 12, 2016, at an event organized to express support for the indigenous people who are resisting the Dakota Access Pipeline (DAPL), Shasta Cano-Martin, Secretary of the Council of the Lummi Nation, spoke. She said that when the coal project came up in 2011 the strong opposition from the wider Bellingham community gave strength and encouragement to the Lummi and enabled the Lummi to take a strong stand themselves.

Furthermore, the collective activism against the GPT had wider social effects. The Lummi Nation and other groups gained broad media attention, especially through the three Totem Pole Journeys, which 
informed and connected many people concerned about tribal sovereignty and the fossil fuel industry across the western States and western Canada. By pooling their resources, the groups recognized that they needed each other to achieve their mutual goals to stop a fossil fuel project that would negatively affect an indigenous community and the city of Bellingham. The coalition was very effective, through communication networks and the ability to generate levels of support, in fighting back several legislative initiatives that tried to set aside the treaty argument.

The Lummi-led coalition, and others like it, could help indigenous communities reframe what environmentalism means and who has the power to be involved in the decision-making [54]. This relationship, however, can be complicated, since there are many different worldviews, diverse and sometimes divergent interests, and levels of power at play. Environmental organizations do not always act in the best interest of indigenous groups [55] and distrust and issues of control are sometimes present. Although indigenous tribes often have the power to protect the environment because of their relationship with federal agencies and their legal sovereignty, nonindigenous persons can try to appropriate this power for their own agenda.

Successful indigenous-nonindigenous alliances entail an equal sharing of power and decision-making between the groups involved. The nonindigenous organizations should ideally aid in strengthening the political power of the indigenous groups involved and contribute resources [56]. Having common political adversaries, a sense of common understanding, and a common agenda allow for a smoother negotiation of group differences [57]. If indigenous and nonindigenous groups come together around a specific agenda to accomplish a certain set of goals, this may help the coalition better deal with unequal power imbalances that may harm indigenous people [55]. Despite existing power imbalances, such alliances create an opportunity for indigenous groups to voice their political opinions, share their resources, and strengthen their self-determination [58].

The movement to stop the GPT illustrated how a tribe's treaty rights enabled them to affect the policy agenda and level past power imbalances among various groups, over issues such as water rights. This and similar coalitions have the potential to help resolve conflicts over tribal fishing rights and create a more equitable and environmentally sustainable society. Such alliances can help improve relationships between environmental, faith-based, and indigenous groups as they work in solidarity towards ecological sustainability [59].

During their opposition to the GPT, the communities of Bellingham experienced something akin to a social movement. Existing groups mobilized and coalesced, new groups arose and organized, and all pursued methods of opposition that seemed to each most apposite. To some extent, such as with the Lummi-led coalition, there was coordination and explicit collaboration. For the most part, the groups decided on their respective courses of action spontaneously and independently, and with mutual respect and gratitude.

It is difficult to imagine how to replicate such a movement in any conscious and deliberate way. Its essence was to a great extent its process of organic self-organization. What is clear is that a great many in the community were motivated to act in some way. They took the trouble either to form new organizations or to move existing institutions in particular directions. To a greater or lesser extent and with greater or lesser clarity, all the groups shared concerns for the environment, for social justice, for local rights of self-determination, and against corporate power. The immediate, large threat of the GPT project made it possible to focus these concerns on a particular object and to galvanize themselves into action.

\section{Conclusion}

This paper identifies and explores a multitude of legal and policy strategies, including civil disobedience, which local communities may employ to protect local values against an expanding neoliberal econ- omy. Specifically, it identifies factors - common core and policy beliefs - enabling unlikely allies to coalesce and achieve greater strength through shared resources, a multi-pronged strategy, and a more diverse constituency. It also underscores the importance of groups acting independently within a broader, self-organizing social movement.

The Bellingham case, in particular, illustrates the special and growing power of U.S. treaty tribes, through their resource rights and moral claims, to effectively protect local ecosystems, and the indigenous as well as non-indigenous communities who depend on them or who care deeply about them. Here, the Lummi Nation helped otherwise disparate advocacy groups recognize how their goals of environmental protection, local sovereignty, social justice, spiritual integrity, and health were interdependent, and collectively threatened by the proposed GPT. The personal accounts of Lummi community members, environmental activists, and faith-based leaders narrated a community's desire for capacity building in a globalized political economy [60].

The Bellingham case serves to remind small-scale fishing communities that their keys to survival in a neoliberal economy may be found in unfamiliar places. This story underscores the value of looking across lines of difference, and even distrust, to identify mutual beliefs and complementary tools, and achieve interdependent goals.

\section{Acknowledgements}

The authors thank Lummi community members and Kurt Russo, a fabulous informant and advocate. However, their comments do not necessarily represent those of the Lummi Nation. They would also like to acknowledge all the environmental, community, and faith-based organizations who shared valuable information with them.

\section{References}

[1] E. De Place, Northwest Fossil Fuel Exports. Sightline Institute. 〈http://www. sightline.org/research_item/northwest-fossil-fuel-exports-2/>, 2014.

[2] The Bellingham Herald. 2016. Timeline: Gateway Pacific Terminal at Cherry Point. The Bellingham Herald. 〈http://www.bellinghamherald.com/news/local/ article76550807.html)

[3] Press Associated. 2016. Protest and oil sheen on Columbia River follow Oregon Train derailment. The Guardian. 〈https://www.theguardian.com/us-news/2016/ jun/04/protest-oil-sheen-columbia-river-oregon-train-derailment

[4] L.Peeples, Coal-Hungry World Brings Tough Choices For Native Americans. The Huffington Post. 〈http://www.huffingtonpost.com/2014/01/30/northwest-coalexports n 4611021.html $\rangle, 2014$.

[5] Henry M. McGee, et al., Coal and commerce: local review of the Gateway Pacific Coal Terminal., Seattle J. Environ. Law 4 (2014), 2014, pp. 283-316.

[6] Jose Gonzalez, Mexican tycoon buys big stake in Seattle's SSA Marine., Seattle Times (2014) 〈http://www.seattletimes.com/business/mexican-tycoon-buys-bigstake-in-seattlersquos-ssa-marine/ $\rangle$.

[7] Jay Taber, Cherry point ownership., Intercont. Cry (2013) 〈https:// intercontinentalcry.org/cherry-point-ownership/>.

[8] Emily Hayes, Hart, Wayne G. Landis, Regional ecological risk assessment of a near shore marine environment: cherry point, WA, Hum. Ecol. Risk Assess. 10 (2) (2004) 299-325.

[9] Joseph K. Gaydos, Sofie Thixton, Jamie Donatuto, Evaluating Threats in Multinational Marine Ecosystems: A Coast Salish First Nations and Tribal Perspective (Ed. Andrea Belgrano)PLoS ONE 10 (2015), 2015, p. e0144861.

[10] Ralph Schwartz, Coal companies buys stake in Gateway Pacific Terminal. Bellingham Her. (2015) 〈http://www.bellinghamherald.com/news/local/ article31057086.html $\rangle$.

[11] Gateway Pacific EIS. Terminal, Environmental impact statement: proposed Gateway Pacific Terminal/Custer spur, EIS Gatew. Pac. Termin. (2015) 〈http:// www.eisgatewaypacificwa.gov/about/who-is-involved $\rangle$.

[12] Martin Associates, The Projected Economic Impacts for the Development of a Bulk Terminal at Cherry Point, Martin Associates, Lancaster, PA, 2011.

[13] Lynda V. Mapes, Northwest tribes unite against giant coal, oil projects, Seattle Times (2016) 〈http://projects.seattletimes.com/2015/local/cherry-points/〉.

[14] Public Financial Management, Inc., 2012. The Impact of the Development of the Gateway Pacific Terminal on the Whatcom County Economy. www.communitywisebellingham.org/wp-content/uploads/2012/03/Communitywise-BellinghamReport-3.6.2012.pdf.

[15] David Burgesser, Carrera Casper, Theo Fray, Kayla Grayson, Walter Haas, Gateway Pacific Terminal Proposal: Environmental Impact Assessment, Huxley College Graduate and Undergraduate Publications, Bellingham, Washington, 2011 Paper 6.

[16] Department of Natural Resources, (2016), Aquatic Reserves. Washington State 
Department of Natural Resources. http://www.dnr.wa.gov/managed-lands/ aquatic-reserves

[17] Merle Jefferson, Lummi nation reviewing proposed deep-water port terminal. Bellingham Her. (2011) 〈http://www.coaltrainfacts.org/docs/WHATCOM-VIEW_Lummi-Nation-reviewing-proposed-deep-water-port-terminal.pdf $\rangle$.

[18] The Glosten Associates, Inc., 2014. Gateway Pacific Terminal: Vessel Traffic and Risk Assessment Study, Rev. A. File No. 12096.02

[19] A. Roberts, Planned U.S. Coal Ports: a swift trip from vital to irrelevant. WoodMacknezie: A Verisk Analytics Business. 〈http://www.woodmac.com/blog/ planned-us-coal-ports-a-swift-trip-from-vital-to-irrelevant/>, 2016.

[20] CommunityWise Bellingham, CommunityWise Bellingham: about us., Community Bellingham (2016) 〈http://www.communitywisebellingham.org/about-us/ $>$.

[21] Coal Power Past, Arch coal bankruptcy: the end of an era, Power Coal (2016) 〈http://www.powerpastcoal.org/arch-coal-bankruptcy-the-end-of-an-era/〉.

[22] D.Robertson, D.Judd, The Structure of Policy Restraint. Glenview, IL; Scott, Foresman, and Company, 1989.

[23] B.Wingfield, M.Miriam, In Pictures: America's Greenest (and Least Green) States. Forbes. 〈http://www.forbes.com/2007/10/16/environment-energy-vermont-bizbeltway-cx_bw_mm_1017greenstates_slide.html>, 2007.

[24] Center for Climate and Energy Solutions (C2ES), Greenhouse gas emissions targets., Cent. Clim. Energy Solut. (2016) 〈http://www.c2es.org/us-states-regions/ policy-maps/emissions-targets $>$.

[25] Yes on I-732. 2016. Yes on I-732. Yes on 732. 〈http://yeson732.org/〉

[26] Frank R. Baumgartner, D. Jones Bryan, Agendas and Instability in American Politics, University of Chicago Press, Chicago, 1993.

[27] John Stark, New group urges involvement in Cherry Point coal terminal permit process., Bellingham Her. (2012) 〈http://www.bellinghamherald.com/news/local/ article22204761.html

[28] Zoltan Grossman, Cowboy Indian alliance and other unlikely environmental alliance., Portside Org. (2014) 〈http://portside.org/2014-04-23/cowboy-indianalliance-and-other-unlikely-environmental-alliances $\rangle$

[29] Speth James Gustave, The Bridge at the Edge of the World: Capitalism, the Environment, and Crossing from Crisis to Sustainability, Yale University Press, New Haven, 2008.

[30] N. Dolšak, A.Prakash, Here's What Many Journalists Missed When Covering the Brexit Vote. Washington Post. Monkey Cage. August 4, 2016.

[31] John Forest Dillon, Municipal Corporations, James Cockcroft and Co, Chicago, 1872.

[32] Christina Hicks, Arielle Levine, Arun Agrawal, Xavier Basurto, Sara Breslow, Caroline Carothers, Susan Charnley, Sarah Coulthard, Nives Dolšak, Jamie Donatuto, Carlos Garcia-Quijano, Michael B. Mascia, Karma Norman, Melissa Poe, Terre Satterfield, Kevin St Martin, Phillip S. Levin, Charting progress towards a sustainable future requires concrete engagement with key social concepts., Science 01352 (6281) (2016) 38-40.

[33] Robert K. Yin, Case Study Research: Design and Methods, Fifth edition, Sage, Los Angeles, 2014.

[34] Thomas A. Birkland, An Introduction to the Policy Process: Theories, Concepts, and Models of Public Policy Making, M.E. Sharpe, Armonk, NY, 2011.

[35] Dallas J. Elgin, Christopher M. Weible, A stakeholder analysis of colorado climate and energy issues using policy analytical capacity and the advocacy coalition framework., Rev. Policy Res. 30 (1) (2013) 114-133. http://dx.doi.org/10.1111/ ropr. 12005.

[36] Earl Babbie, The Practice of Social Research, Wadsworth Cengage Learning, Belmont, CA, 2010.

[37] Daniel L. Boxberger, To Fish in Common: The Ethnohistory of Lummi Indian Salmon Fishing, University of Nebraska Press, Lincoln, NE and London, 1989.

[38] Treaty of Point Elliot. 1855. Treaty of Point Elliot, 1855. Governor's Office of Indian Affairs. 〈http://www.goia.wa.gov/treaties/treaties/pointelliot.htm〉

[39] Michael R. Anderson, Law and the protection of cultural communities: the case of Native American fishing rights., Law Policy 9 (2) (1987) 125-142. http:// dx.doi.org/10.1111/j.1467-9930.1987.tb00402.x.

[40] Charles Tanner Jr, Bigotry, Calls for Violence, Follow Protest of Tribal Treaty
Fishing., Institute for Research and Education on Human Rights, 2016 〈http:// www.irehr.org/2016/05/13/bigotry-calls-violence-follow-protest-tribal-treatyfishing/>.

[41] Washington Department of Ecology, Environmental review: gateway Pacific Terminal at cherry point proposal., Dep. Ecol.: State Wash. (2016) 〈http://www. ecy.wa.gov/geographic/gatewaypacific/>.

[42] PFM Group. 2015. The Proposed Gateway Pacific Terminal and Key Impact Issues for the Whatcom County Economy. 〈http://www.communitywisebellingham.org/ wp-content/uploads/2015/06/PFM-2-Report-FINAL-FINAL.pdf $\rangle$

[43] CommunityWise Bellingham. 2012. Coal Train Traffic to Canada and Gateway Pacific Terminal: An Analysis of the Coal Trains Are Coming Anyway Claim and its Implications for Local Taxpayers. 〈http://www.communitywisebellingham.org/wpcontent/uploads/2012/06/CWB-Report-Coal-Train-Traffic-to-Canada-andGateway-Pacific-Terminal1.pdf $\rangle$

[44] D.Whatcom, 〈http://www.coaltrainfacts.org/ $\rangle, 2013$

[45] Jane Ann Morris, Help, I've been colonized and I Can't Get Up....: take a Lawyer and an Expert to a Hearing and Call Me in Decade, in: Dean Ritz (Ed.)Defying Corporations, Defining Democracy: A Book of History and Strategy, Apex Press, New York, 2001.

[46] Community Environmental Legal Defense Fund. 2016. 〈www.celdf.org〉

[47] 42 US Code $\S 1983$

[48] Andrew Truck, Lummi nation won't budget in opposition to Gateway Pacific Terminal., Big Horn Cty. News (2015) 〈http://bighorncountynews.com/news/ unstoppable-force-immovable-object $\rangle$.

[49] Samantha Wohlfeil, Army corps rejects permit for coal terminal at Cherry Point., Bellingham Her. (2016) 〈http://www.bellinghamherald.com/news/local/ article76545117.html $\rangle$.

[50] Clark Williams-Derry, Coal exports markets in freefall., Sightline Inst. (2015) 〈http://www.sightline.org/2015/02/02/coal-export-markets-in-freefall/〉.

[51] A. Roberts, Planned U.S. Coal Ports: a swift trip from vital to irrelevant. WoodMacknezie: A Verisk Analytics Business. 〈http://www.woodmac.com/blog/ planned-us-coal-ports-a-swift-trip-from-vital-to-irrelevant/>, 2016.

[52] Joel Connelly, Goldman sachs bails out on Cherry Point coal port builder, Seattle PI (2014) 〈http://blog.seattlepi.com/seattlepolitics/2014/01/08/goldman-sachsbails-out-on-coal-port-builder $/\rangle$.

[53] J.James, Indigenous Day of Action: Break Freee PNW. March Point, Anacortes, WA. Youtube.com 〈https://www.youtube.com/watch?V=QJ2LIMPYCDo〉, 2016.

[54] Anna J. Willow, Re(con)figuring alliances: alace membership, environmental justice, and the remaking of indigenous-environmentalist relationships in Canada's Boreal Forest., Hum. Organ. 71 (4) (2012) 371-382. http://dx.doi.org/10.17730/ humo.71.4.x267775756735078.

[55] David E. Toohey, Indigenous peoples, environmental groups, networks and the political economy of rainforest destruction in Brazil., Int. J. Peace Stud. 17 (1) (2012) 73-97.

[56] Valerie Crist, Protecting Place Through Community Alliances: haida Gwaii Responds to the Proposed Enbridge Northern Gateway Project. (Master's Thesis), University of British Columbia, Vancouver, B.C, 2012.

[57] Jun Kamata, Coalition Building for Indigenous Justice: American Indian Sovereignty and Struggles in Ward Valley, University of California, Los Angeles California, 2004.

[58] Lynne Davis, Heather Yanique Shpuniarsky, The spirit of relationships: what we have learned about indigenous/non-indigenous alliances and coalitions., in: Lynne Davis (Ed.)Alliances: Re/Envisioning Indigenous-non-Indigenous Relationships, University of Toronto Press, Toronto, 2010.

[59] Caitlyn Vernon, What new responsibility? Taking responsibility for justice and sustainability in British Columbia., in: Lynne Davis (Ed.)Alliances: Re/Envisioning Indigenous-non-Indigenous Relationships, University of Toronto Press, Toronto, 2010.

[60] Noriko Ishiyama, Environmental justice and American Indian Tribal Sovereignty: case study of a land-use conflict in Skull Valley, Utah, Antipode 35 (1) (2003) 119-139. http://dx.doi.org/10.1111/1467-8330.00305. 